Open Access

\title{
Serial entrepreneurs in the Waterloo ecosystem
}

\author{
Prescott C. Ensign ${ }^{1 *}$ and Steve Farlow ${ }^{2}$
}

\author{
* Correspondence: ensign@wlu.ca \\ ${ }^{1}$ Lazaridis School of Business \& \\ Economics, Wilfrid Laurier \\ University, Waterloo, Ontario, \\ Canada \\ Full list of author information is \\ available at the end of the article
}

\begin{abstract}
The framework for this study is based on the research and literature related to serial entrepreneurs and entrepreneurial ecosystems. Our sample is 12 serial entrepreneurs within a single context - the Waterloo Region - that has been ranked as one of the top start-up ecosystems in the world. In 2012, it was ranked 16th with $32 \%$ of the start-ups identified as being led by serial entrepreneurs. The study provides an understanding of the characteristics that define a mature ecosystem, with specific input on the Regional Municipality of Waterloo, Ontario, Canada. We profile the 12 entrepreneurs to provide a review of their businesses, the contributions they have made within their ecosystem, and their statements on what they have learned in the process of leading multiple ventures. This research may be useful for communities and nations that seek to focus on entrepreneurship as a means for economic growth. It should also stimulate further research on contextual issues and examine serial entrepreneurs within their own ecosystem.
\end{abstract}

Keywords: Serial entrepreneurs, Entrepreneurial ecosystem, Venture creation, Waterloo Region

\section{Background}

Entrepreneurs have been viewed as the engines that can move the economy forward, providing new businesses that add to entrepreneurial ecosystems in geographic regions (Grebel 2007; Grebel et al. 2003; Metcalfe 2004; Schumpeter 1934; Witt 1998). But entrepreneurs are unevenly distributed individually and geographically (Acs and Armington 2004; Audretsch et al. 2006; Fritsch 2008). As Ucbasaran et al. (2008) note, entrepreneurial behavior is increasingly recognized as being heterogeneous with regard to variations in the level and nature of experiences.

It is useful to make some distinction among entrepreneurs that delineate this experience factor. Westhead and Wright (1998) provide a starting point by defining entrepreneurs as those who start, inherit, or purchase a business. The result is that research focuses on the different types of entrepreneurs: first-time (novice) entrepreneurs and experienced (habitual) entrepreneurs. Habitual entrepreneurs are those that have had ownership in more than one business, sequentially (serial entrepreneurs) and/or concurrently (portfolio entrepreneurs) (Ucbasaran et al. 2008). Habitual entrepreneurs are an important group to study because of the large number of businesses they create and the unique way that they participate in venture creation activities (Spivack et al. 2014).

C 2016 Ensign and Farlow. Open Access This article is distributed under the terms of the Creative Commons Attribution 4.0 International License (http://creativecommons.org/licenses/by/4.0/), which permits unrestricted use, distribution, and reproduction in any medium, provided you give appropriate credit to the original author(s) and the source, provide a link to the Creative Commons license, and indicate if changes were made. 


\section{Conceptual frameworks}

One way to look at habitual entrepreneurs is to examine them from the perspective of psychological capital-the impact of behavior relative to success and failure (Baluku et al. 2016). Some investigations have focused on the psychological processes that motivate habitual entrepreneurs, such as the concept of addiction (Morris et al. 2012; ReyMartí et al. 2015; Spivack et al. 2014; York et al. 2015). A second way is to use a human capital approach to examine the correlation between task relatedness (vis-à-vis the accumulation of entrepreneurial experience, knowledge, and skills) and entrepreneurial outcomes (Unger et al. 2011). A third conceptual approach is to take a social capital perspective. Social capital here refers to the benefits entrepreneurs derive from their social networks. As Baron (2015) notes, social capital and social network studies have focused on various descriptors with regard to its nature and distinguishing characteristics. He suggests that further research needs to look at entrepreneurship from a social capital perspective.

A fourth way to look at habitual entrepreneurs is to use an entrepreneurial ecosystem perspective. This view is holistic and seeks to understand the institutions and structures (formal and informal) that help to develop and maintain entrepreneurial human capital within a specific context or ecosystem (Baron and Markman 2003; Davidsson and Honig 2003; Lengyel et al. 2015; Mason and Brown 2014; Napier and Hansen 2011; Westlund and Bolton 2003). The ecosystem helps entrepreneurs build social capital because of the abundance of individuals involved in entrepreneurship. In effect, they have opportunities for networking and exchange of ideas within the ecosystem because of the ecosystem. In the case of serial entrepreneurs, they learn from each other's successes and failures, hire people that may already have experience in an entrepreneurial venture, and recycle their money and knowledge back into the ecosystem.

This study looks at a sample of 12 serial entrepreneurs-defined as those who have had more than one venture creation experience-who are situated in the Waterloo, Ontario, region. For this study, we focus on the context where entrepreneurs build a business (Ucbasaran et al. 2001). Our sample of serial entrepreneurs is set in the Waterloo entrepreneurial ecosystem. They primarily draw from and contribute to the network or amalgam of individuals, organizations, and resources within this setting. This ecosystem or context can provide both formal and informal benefits as well as, perhaps, some limitations. More specifically, an entrepreneurial ecosystem can stimulate successful economic activity resulting in subsequent innovation and commercialization-whether seen as discreet iterations or a continuous, seamless process.

\section{The Waterloo entrepreneurial ecosystem}

An entrepreneurial ecosystem approach provides a contextual perspective for analyzing and understanding the serial entrepreneurs and their social network (Feld, 2012; Hathaway, 2013; Isenberg, 2011). The definition of entrepreneurial ecosystems is based on Mason and Brown's (2014; p. 5) synthesis of the literature. An entrepreneurial ecosystem is:

a set of interconnected entrepreneurial actors (both potential and existing), entrepreneurial organizations (e.g. firms, venture capitalists, business angels, banks), institutions (universities, public sector agencies, financial bodies) and entrepreneurial 
processes (e.g. the business birth rate, numbers of high growth firms, levels of 'blockbuster entrepreneurship', number of serial entrepreneurs, degree of sell-out mentality within firms and levels of entrepreneurial ambition) which formally and informally coalesce to connect, mediate and govern the performance within the local entrepreneurial environment.

The Waterloo Region of Ontario, Canada, has been recognized as an entrepreneurial hotbed that produces, attracts, and retains serial entrepreneurs. In the Global Start-up Ranking 2012 by Start-up Genome (now Compass), Waterloo is ranked $16^{\text {th }}$. On the index of characteristics, $32 \%$ of the start-ups in Waterloo were done by serial entrepreneurs. Those with $50 \%$ or more were Silicon Valley and New York City (both 56 \%); Los Angeles (55\%); Boston (51 \%); and Moscow and Vancouver (50 \%). Those with $40 \%$ or more were Tel Aviv (47\%); Sydney (45\%); Toronto (44\%); London (42\%); and Berlin (40\%). Those with $30 \%$ or more were Paris (37 \%); Melbourne (33\%); and Waterloo and Singapore (both $32 \%$ ). Most of those on the list have significant populations compared to the Waterloo Region with 500,000 residents. This is an important point since the 2012 data indicated that the Waterloo ecosystem had a start-up density second only to Silicon Valley and $50 \%$ higher than the third ranked region.

The Global Start-up Ecosystem rankings attempt to measure the world's leading start-up ecosystems based on broad infrastructure of talent, education, entrepreneurs, venture capital, and companies that make up a start-up community. The report also measures these ecosystems based on quality of talent, pool of venture capital resources, experience and mentorship provided by start-up founders, market reach of their companies, and the performance and exit value of companies.

\section{Descriptors of Waterloo's entrepreneurial ecosystem}

There are many factors that make the Waterloo ecosystem a remarkable context for the creation of new ventures. These are outlined in Table 1.

Waterloo has a knowledge-based economy including firms in the high-tech and insurance sectors as well as two universities. Waterloo's technology sector has hundreds of high-tech firms. The dominant and largest technology firm is Research In Motion/ BlackBerry, founded in 1984. Many high-tech companies (with headquarters elsewhere) have research and development centers within the Waterloo ecosystem: Sybase, Google, Oracle, Intel, McAfee, NCR Corporation, Electronic Arts, Christie Digital, and Agfa. Waterloo also has the Perimeter Institute for Theoretical Physics and Institute for Quantum Computing.

With regard to the universities, both have a strong emphasis on entrepreneurship. Undergraduates at the University of Waterloo (UW) may complete up to 24 months of co-op placements; Wilfrid Laurier University (WLU) students up to 12 months. UW has a start-up incubator for students called Velocity Garage. WLU Lazaridis School of Business and Economics has the Schlegel Center for Entrepreneurship, and students who graduate are prepared to embark on an entrepreneurial journey via the LaunchPad. And jointly, UW and WLU join forces through the Accelerator Centre.

The Waterloo ecosystem also has structured entrepreneurship centers. Communitech-established in 1997 by local tech leaders-supports a tech cluster of nearly 1000 companies at all stages of their growth and development-including stalwart veterans 
Table 1 Characteristics of an entrepreneurial ecosystem ${ }^{a}$

\begin{tabular}{|c|c|}
\hline Place-specific assets & Distinguishing features of Waterloo \\
\hline 1. Large high-tech firms & Research In Motion (RIM)/BlackBerry \\
\hline - Entrepreneur blockbuster led & Initially Mike Lazaridis and Douglas Fregin \\
\hline - Talent magnets & Global recruiting \\
\hline - Business training & Acquire skills as technology manager \\
\hline - Produce spin-offs & Downsizing led to new start-ups \\
\hline 2. Universities & Undergraduate and graduate programs \\
\hline - University of Waterloo & Engineering/technology with co-op program \\
\hline - Wilfrid Laurier University & Business/management with co-op program \\
\hline - Research Centers & Innovation, entrepreneurship and R\&D \\
\hline 3. Entrepreneurial recycling & Exits and cash outs \\
\hline - Reinvesting wealth & Business angels \\
\hline - Reinvesting skills & Serial entrepreneurs \\
\hline - Reinvesting experience & Mentors, advisors, teaching \\
\hline 4. Information rich & Access to information and knowledge \\
\hline - Formal & Forms, blogs, organizations, etc. \\
\hline - Informal & Connector socio-cultural norm \\
\hline 5. Deal makers & Informal key linchpins \\
\hline 6. Culture of inclusion & All means all \\
\hline - Open to newcomers & Wide sharing of knowledge and experience \\
\hline - Failures are not shunned & Philosophy of experimentation and failure \\
\hline - Porous boundaries & Accepts moving from one company to another \\
\hline 7. Funding sources & Critical mass for seed and start-ups \\
\hline - Angel investors & Cashed out and current entrepreneurs \\
\hline - Accelerators and incubators & Start-up to scale-up \\
\hline - Venture capital & Local investors connected to internationals \\
\hline 8. Structured entrepreneurship help & Industry-led innovation cluster \\
\hline - Centers of support & Communitech, incubators, accelerators, etc. \\
\hline 9. Service providers & Lawyers, accountants, consultants, etc. \\
\hline 10. Local support & Municipal and regional \\
\hline
\end{tabular}

Suggested by Mason and Brown (2014; pp. 8-12); Napier and Hansen (2011; pp. 1-24); and Ucbasaran et al. (2001)

looking to rejuvenate. It supports companies in commercializing innovation and technology, with the goal of creating successful global businesses. Some of its features are Communitech Hub, Waterloo Innovation Summit, Entrepreneurs-in-Residence, mentoring programs, and sponsored events. The ecosystem also has active angel investors, recycling their profits back into the community to help other entrepreneurs with funding. In the past 5 years, 1845 new technology start-ups have been started in the Waterloo Region. A 2013 PricewaterhouseCoopers survey attributes more than 20,000 jobs to the region's vibrant ecosystem.

\section{Methods}

The research approach was to select a sample of 12 serial entrepreneurs who operate in the context of this technology-centered, entrepreneurial environment. They were identified by key persons within the ecosystem, personal understanding of the Waterloo social network, and coverage in multiple publications. The information on these people 
was obtained from publicly available web pages on the entrepreneurs and firms as well as newspaper articles and blogs that include biographical information, self-reported insights and reflections, and involvement in the community. As such, this provides a profile of each serial entrepreneur's businesses, contribution to the ecosystem (service), insights, and reflections. The findings are qualitative in terms of presenting descriptive information for each serial entrepreneur. We have also summarized their views, reflections, and advice in the final section of the paper.

\section{Serial entrepreneurs: ventures and contributions in the ecosystem}

The focus in this section is on the serial entrepreneurs themselves. The sample has been chosen because their venture activities are within the context of the entrepreneurial ecosystem in the region of Waterloo-consisting of the cities of Cambridge, Kitchener, and Waterloo. The venture activity data for each entrepreneur is provided in two sections. The first section entails an overview of the enterprises each entrepreneur leads and his/her contribution to the local ecosystem. The second section provides their personal input on what they have learned in their path as entrepreneurs.

Randall J. Howard is deeply connected to the ecosystem, starting with a degree in math at the UW. His first endeavor was as co-founder of Coherent in the US. He returned to Waterloo and never left. He is well known for having founded (1984) and grown one of the early tech success stories in Waterloo-Mortice Kern Systems-an enterprise software vendor that had revenue of $\$ 50 \mathrm{M}, 400$ employees, and became a public company before it was sold to PTC for $\$ 304 \mathrm{M}$. He is co-founder and partner of VERDUXUS-a transatlantic boutique fusing a network of serial technology entrepreneurs with investment in a proactive and hands-on methodology to build worldleading, high-growth technology organizations. He is also CEO of Middlebrook Corp. These are just a few of the technology ventures with his involvement.

His contributions to the local ecosystem are even more impressive. He was cofounder of Communitech-a local organization that is the backbone for the development of entrepreneurship within the ecosystem. To jump-start the Waterloo investment scene, he helped launch Golden Triangle Angelnet for which he received the Canadian Angel of the Year Award in 2014. He has served in a board or advisory role at many firms (many acquired or taken public) as well as the Dean's Advisory Council at WLU's Lazaridis School of Business and Economics.

His current interests and community service include social entrepreneurship ventures. A recent project to establish the China Angel Mentorship Program, aimed at bringing young entrepreneurs from Canada and China together to promote global entrepreneurship. A headline statement on his home page reads: "Exploring the intersection of technology, strategy, investment, and social innovation."

Yvan Couture has close ties to the local ecosystem. He claims his path to entrepreneurship started when he failed miserably in his first business venture. After earning his MBA from the Lazaridis School of Business and Economics at WLU, he launched his technology career at Focus Automation. In 1991, he created TAAZ-a consulting firm serving emerging technology companies-and stayed there for 9 years. He moved to Mitra-a healthcare informatics leader-and then led negotiations for its sale in 2002. He has been an active angel investor since the sale of Mitra. His career at Primal 
started as a seed investor. He joined the founder as CEO in 2006, taking the founder's innovations to drive the company forward. He has served as chairman of the Official Community - the first company to commercialize a business model that intersects e-commerce, social media, and entertainment.

He was a co-founder of Communitech-the entrepreneurship center that was established with Randall Howard-and co-founder of the Atlas Group. According to public sources, Couture is driven by two interrelated passions: helping great technology entrepreneurs turn disruptive ideas into successful companies and creating wealth from these companies that stays in the community. His own comments repeat this: "I love disruptive technology and the people who create them. I partner with exceptional innovators or entrepreneurs and help them build real commercial enterprises."

John Bell is described as an entrepreneur at heart. In Bell's own words, he started his first business after being fired from another. "I never wanted the humiliation of cleaning out my desk drawer - that's the day I became an entrepreneur." He started ShredTech with $\$ 10,000$ he borrowed from his mother. The first year it had sales of $\$ 70,000$. Sales reached $\$ 15 \mathrm{M}$ by the time he sold it in 1995 . He could have retired but chose to buy a local factory-Polymer Technologies-that was poised to put 90 people out of work. In 1995 he founded Onbelay Investments. Since then, he has been scouting opportunities in many industries and investing along the way. He believes it is not just about the products but about the people. Some describe him as showing others the way.

Bell indicates that community work is in the family DNA. He fills his calendar with a list of community work including a hefty share of board work. These contributions have included Waterloo Regional Police Services Board, President's Advisory Council and Campaign Cabinet at WLU, and work with two regional chambers of commerce to form the Prosperity Council.

Razor Suleman graduated from WLU's Lazaridis School of Business and Economics and MIT's Entrepreneurial Masters Program. He has many ventures to his credit. He created a branded merchandising company-Razor's Edge-when he was still a student. In June 2002, he founded Snap-the Amazon.com of branded promotional products. Its technology has powered the stories of many large companies. Snap was acquired by Integrus with a return of eight times investors' capital. He was founder and CEO of I Love Rewards (2002-2012) - the first SaaS rewards and social recognition company. It was backed by Sequoia VC and raised $\$ 35 \mathrm{M}$ in three venture capital rounds.

He is the founder of Achievers-a company focused on employee rewards and social recognition (also backed by Sequoia). Business Insider (July 2, 2015) reported that he sold it to Blackhawk Network for $\$ 110 \mathrm{M}$ in cash rather than make it an IPO because they were willing to keep the team on board and keep the brand. He is a partner in Alignvest Management Corporation-an international alternative investment management firm. He has guided two companies-Razor's Edge and I Love Rewards-to a place on the PROFIT 100 ranking of Canada's fastest growing companies.

Marc Morin is a graduate of the two universities in Waterloo's entrepreneurial ecosystem. His undergraduate degree in electrical engineering is from UW and he completed an MBA at WLU. He worked as a software engineer at HP (1987-1996) before starting his first venture with two UW graduates. PixStream developed specialized digital video-streaming technology. It was acquired by Cisco Systems for $\$ 554 \mathrm{M}$ in 
December 2000 and subsequently shuttered. ${ }^{1} \mathrm{He}$ soon after co-founded Sandvine, a provider of intelligent broadband networking equipment. He co-founded Emforium Group Inc., serving as president and CEO. It provided Internet-based software solutions for small business including trademarked ALL-IN Software.

He co-founded Auvik Networks with two successful entrepreneurs who are also graduates of both UW and WLU. Auvik Networks is a cloud-based network operations/ management system. The trio received $\$ 6 \mathrm{M}$ in seed funding from Celtic House Venture Partners, Rho Cana Ventures, and Business Development Bank of Canada in 2013. Morin explained the significance of his social network developed in the university: "Those connections are invaluable. The people I met in my classes have made all the difference to my success. One is a $\mathrm{VC}$ and one is $\mathrm{CEO}$ of a large telecom provider." As alumni, Morin and co-founders enjoy being able to nurture young talent from both their alma maters, including hiring co-op students.

Carol Leaman was profiled in a Business Insider (April 19, 2015) article with the headline: "Why this woman turned down a fabulous job at Google." She was in the midst of selling her company PostRank - the third tech company she would have sold. They wanted her in California so she decided to sell the company to Google instead. At the time she was advisor and CEO at Axonify, a company that turns corporate training into games. She chose to buy Axonify, took all of her savings, and found a partner to take on sales. The two worked without a paycheck for a year.

She admits that as a 17-year-old, she knew what she wanted to be, the CEO of her own company. Prior to PostRank, she started two other companies: RSS Solutions (enterprise class manufacturing software) and Fakespace (a high-end virtual reality company). She took Fakespace from $\$ 3 \mathrm{M}$ to $\$ 30 \mathrm{M}$ in revenue before an acquisition in 2003. She sold RSS Solutions in 2006. Axonify—the company she gave up a paycheck for and decided to buy-is still thriving. Under her leadership, the company grew from one customer and two employees to $100+$ customers and $\$ 10 \mathrm{M}$ in revenue.

She is a role model within the ecosystem, especially for other women. She was the first executive-in-residence at Communitech and received the Waterloo Region Entrepreneur Hall of Fame's Intrepid Award in 2011. She is an in-demand speaker, an advocate for becoming an entrepreneur, and serves on several local boards including the Waterloo Region Economic Development Corporation.

Michael Alkier Jr. grew up in Waterloo and is a WLU Lazaridis School of Business and Economics graduate. His entrepreneurial pursuits are unique. He sold one large technology company, started another, and is involved in three enterprises in separate industries-software, cars, and music. He worked for SAP for 4 years before starting Omnilogic Systems Group with three partners in 1994. Omnilogic was a SAP softwareconsulting business that had 550 employees and $\$ 90 \mathrm{M}$ in sales before it was sold to PricewaterhouseCoopers in 2000. The success of Omnilogic gave him the opportunity to invest in other businesses. He and a partner started Ideaca in 2000, funded by the partners and the investment firm XDLi. Ideaca was a software-consulting company that provides management consulting, implementation, and support services. It acquired People Edge Inc. in 2011. Ideaca was acquired by Hitachi in 2013.

He partnered with his father in Alkier Motor Sports, a company with dealerships in the Waterloo Region. On the music side, he has only used that interest as an investor. He has invested in Round13 Capital that was established in 2013. In addition to 
bringing founders with exits as limited partners, the focus is on bringing them together to serve as mentors. Another investor with Round13 Capital is Randall Howard profiled earlier. The money earned keeps getting recycled-most of it within the ecosystem.

Dan Mathers has had a long and varied career. He was founding president and CEO of IceFyre Semiconductor (2001-2005). IceFyre was a venture-backed fabless semiconductor company focused on developing wireless chipsets for home multimedia applications. He was founding president and CEO of eSight Corporation (2006-2009), a privately funded medical device company aimed at helping vision-impaired individuals regain functional sight. He holds a US patent (issued March 2012) on an apparatus and method for augmenting sight.

$\mathrm{He}$ is founding president of IronBit Consulting (2005-present). It is a mentorconsulting business specializing in sales and business development strategy; corporate structure and partnership strategy; and structuring commercial transactions. A recent venture, as co-founder and partner, is IronSpace Executives Inc. (2013-present). It is a full-service executive practice providing fractional executives, management consulting, coaching and mentoring, and investment strategy development.

Some of his contributions to the local ecosystem include advisory support as well as mentoring tech start-ups at Communitech; founding director and entrepreneurin-residence for the local region of MaRS (a provincially funded accelerator); founding director of the Lewis Vision Foundation; and director of the Creative Enterprise Initiative. His enthusiasm and expertise have been invaluable to many.

Dan Silivestru graduated with honors in science and physics from UW and stayed in the local ecosystem. But he claims he is self-taught with regard to the software development process. He studied a manual, decided it was the career he wanted, and never looked back. Co-founder of tinyHippos Inc., he served as chief technology officer from 2009-2011 before it was acquired by RIM in 2011. For several years, he served as an "open source ambassador" at RIM. In 2013, he co-founded bitHound whose services help development teams gain clear, real-time, and instantly actionable insights into the condition of their software so they can focus on critical issues, save time, and ship with confidence.

Chris Reid has used his degree in electrical engineering from UW to jump-start his career in entrepreneurship. In an Ontario Center of Excellence blog, he writes: "I think entrepreneurship chose me." Growing up, he could not not think about business. And today, he admits he would not do anything else. His first start-up was Snapsort, founded with two other UW graduates. The trio raised $\$ 500 \mathrm{k}$ from undisclosed investors in 2011. They spent 2 years developing their recommendation platform. Snapsort collects reviews, prices, and product information for online shoppers. The idea for his next start-up Sortable came out of Snapsort. It is designed to help publishers maximize ad revenues from websites. Prior to its move to a local strip mall, it was located in UW's software, hardware, and science start-up incubator-the Velocity Garage. As a young entrepreneur, he has capitalized on the Waterloo tech ecosystem by making connections and finding software engineers to help grow Snapshot.

Ted Hastings completed an undergraduate degree in business at WLU and then joined Deloitte \& Touche LLP as a senior associate (1997) and became a chartered accountant in 1998. He left to join Endgame Systems (a sales and software company) where he served as their CEO for a year before becoming CEO of Global Beverage Group in 2002. He then 
became president of Geosign Corporation and after American Capital bought Geosign and formed Moxy Media (2007); he assumed the role of president and CEO. This was his path to becoming one of Waterloo's most successful entrepreneurs.

His impressive track record of raising capital began with the private equity financing of $\$ 160 \mathrm{M}$ - the largest private equity financing in Canadian history. He founded Rebellion Media Group in 2012-a digital media company that creates and acquires digital media properties in health, technology, and other areas. The total equity funding for this company started with $\$ 5.5 \mathrm{M}$ in the first round. Thirteen months later, Rebellion Media acquired 13 digital media properties. In December 2014, he was named President of Perk.com.

High tech dominates his volunteer work mentoring start-up companies. In his statement to a blogger's (WordPress (October 7 (2013)) interview question on why he volunteers, he stated:

Because people did it for me. Very early in my career some incredibly talented, competitive individuals took time out of the day and helped me along with my business planning, my hiring strategies, my financing plans, when I got myself stuck in a jam they answered my phone calls. They didn't do it for a fee or to sit on my board or to be a paid advisor. They did it because they had something to give back to the community. It's that simple; someone did it for me and I just feel like the only way I can thank those individuals... is to give back to those early stage companies.

Ali Asaria studied computer engineering at UW. Ali founded Well.ca in 2008 after working at RIM in various roles. While at RIM, he created BrickBreaker-a popular mobile game-in his spare time. The idea for Well.ca-Canada's largest online retailer of health, beauty, and baby products-came after watching sales at a retail pharmacy where his father was a pharmacist. He was developing websites and decided to try selling those products online. The company was named as one of Profit Magazine's Hot 50 in 2009. He closed a round of private funding in July 2009 worth $\$ 1.1 \mathrm{M}$.

After Well.ca was acquired, he founded Tulip Retail. He raised \$2.4M (October 2013) in funding for Tulip Retail from SoftTech VC, Founder Collective, BoxGroup, Lerer Hippeau Ventures, iNovia, Promus Ventures, KIMA Ventures, Matt Mullenweg (founder of WordPress), the founders of BufferBox, and Greg Kidd (early investor in Twitter and advisor to Square). The "Tulip Commerce Engine" pulls product, customer, and transactional information into a single, cloud-based hub that allows retailers to enable seamless consumer experiences across their store, website, and mobile storefronts. Though listing its contact presence as the City of New York, Tulip Retail is headquartered in the Waterloo Region.

Among his contributions to other entrepreneurs and businesses within the local ecosystem are mentor at Communitech Hyperdrive, mentor at the University of Waterloo Velocity Garage, mentor at Highline (a VC-backed Accelerator Program), and advisor to Buffer Box (a start-up from UW that was acquired by Google). Hyperdrive in 2015 transformed to Rev Accelerator; according to Steve McCartney, VP of Start-up Services at Communitech:

In 2012, we were worried we would lose our best start-ups to the U.S. and Hyperdrive was designed to address the perceived lack of early stage mentorship and investment 
available in Canada. That's simply not a worry anymore. We are producing about 500 start-ups a year in the Waterloo Region, and most of our companies who go to U.S. accelerators like YC, move back home to build their companies. The gap now, is how do we take those successful start-ups and turn them into globally competitive businesses. Rev will help to solve the shift from a product focus to a sales focus - helping them remove any barrier that stands between them and rapidly growing sales and revenue.

\section{Serial entrepreneurs: what they have learned}

This section focuses on statements made by the 12 serial entrepreneurs with regard to the things that really mattered for their success. Our sample of serial entrepreneurs echoed each other frequently, but that is not to say that contradictory statements and idiosyncratic views were absent. ${ }^{2}$ All of the things they have shared are publically available statements. Some statements were included in James Bowen's book, The Entrepreneurial Effect: Waterloo (2011). Some were included in articles written by reporters, especially those developed primarily for the Waterloo ecosystem. Others were taken from the entrepreneur's own blog or business website.

Randall J. Howard states in his blog-"beware technology overemphasis; generous $R \& D$ funding in Europe seems to encourage more of an engineering mentality than a market-driven one. Things stay too long as "science projects" and the culture and skills to get the project to market seem to suffer. He sees commonality worldwide, but idiosyncrasies too. Don't get trapped up in your own technology."

On passion or purpose, his advice is: "given the amount of time you will spend, it better be something you enjoy. Positive energy is infections, but criticism is important too." On great people around you, he indicates that stellar people are the most important ingredient in a venture's success. Howard has made significant contributions to the local ecosystem so the following statement rings true: "he feels that he owes an obligation to the next generation and is giving back through start-up mentoring."

Yvan Couture in his entry in Bowen's (2011) book writes: "Real entrepreneurs hear opportunity whispering; they see things much earlier than everyone else and venture into uncharted territory. They respond to that whisper; they don't listen to those who question their sanity and continue to persevere." Couture also indicates in the book that entrepreneurs have the spark that starts these new enterprises; with regard to funding, he thinks the primary benefit is cash (even if $\mathrm{VC}$ funding also provides other kinds of assistance).

On people and the venture, he focuses on: "Execution; building the right team, get commercial traction, and show growth. Your mission is to go from being a possibility to becoming a probability." On his perception of the ecosystem he offers: "The advice and mentoring, particularly in the Waterloo Region, can be gained from many sources we have available."

Razor Suleman in Canadian Business (September 25, 2007) describes his leadership approach/style in the following words: "I'm an over-communicator. I'm all about giving our team real-time information and empowering them to make the best decisions for the company. I don't believe in micromanaging. If you have to micromanage someone you have the wrong person. I have a lot of trust in the people that we have on board. 
We're very open and transparent. We're willing to share with other companies. We do that a lot with our blog."

Marc Morin shared his thoughts on Auvik Networks and his team. On the most challenging/rewarding aspect of starting your own business, he states: "There are a number of make-or-break factors that require a lot of your attention and effort; hiring the right team, finding the right funding, doing the right things to execute on your plan. The key is to stay focused and of course correct as you go. Going from an idea to a strategy to actually achieving it is very satisfying. It underscores that anything is possible. Just try and don't be afraid of things not turning out the way you planned. They never do! But the only failure is not trying."

On Waterloo Region's entrepreneurial ecosystem, he states: "We're all proud to be part of one of the biggest and best start-up communities in Canada. Having access to so many resources in one place - VCs, fresh talent coming out of the university, fellow start-up founders - creates opportunities that might not exist otherwise."

Carol Leaman in a Tech Talk (2012) interview states: "Build something that matters, build something that matters in a market, build something that actually has a market! Get as much advice from experienced people - and listen to it - as you possibly can. Choose to work with people very carefully, spend your money very, very wisely. Her specific advice to women is: Females in tech, you're in a great place. It's very easy to get noticed, get in demand, and be able to shine as a woman in tech. Look for every opportunity, don't be shy, go for it, you can do it. You actually have a leg up because you're female."

In Bowen's (2011) book, she provides more input: "Too many times the idea you believe in is ahead of its time or past its prime and you fail to recognize that and act appropriately. Stay on top of market signals and when things start to change, don't hesitate to react swiftly. No denial, no delay, make those tough choices. Take the lean approach wherever possible and build the organization in lock-step with the market." On advice for those first time entrepreneurs, she writes: "You'd better have a clue that someone values your idea in a way that would compel them to spend money. Don't hire your friends, don't hire your family. Don't spend time dreaming up big job titles. Set a tone that is fair, reasonable, open, and be consistent. Finally, pay attention to those expense reports. Cash flow is vital in an early stage or pre-revenue company."

Michael Alkier Jr. in an article in The Record (December 10, 2011), he states: "the businesses feed your passion for entrepreneurship. Try to be the best at what you do. Always look for how to improve offerings." Perhaps reflecting on how his ventures started, he states: "Ideaca's size is an advantage. We are still small enough to be nimble and friendly, but large enough to have the capabilities to compete with the larger firms. Even within Ideaca, we are always looking for new ways to expand the business, new lines of business, new geographies, and how to improve our business. So the nature of the business is that you have to be entrepreneurial all the time, and we encourage all of our people to think that way." Through the auto dealerships, he has gotten to know a lot of local business people. In terms of the local ecosystem, he hires a lot of students from the universities.

Dan Mathers starts his entry in Bowen's (2011) book with the comment: “There's a lot to learn for first time entrepreneurs, and a lot to learn for second time entrepreneurs, and a lot to learn for third time entrepreneurs! You have to love learning and 
the best way to get training is by doing." He acknowledges the reality that when starting out you will likely need to do everything for yourself or with a small team. Does this preclude the help of outsiders? No, but inevitably even the strongest of allies will not be able to shoulder much of the load that falls on the founder and his/her venture team. Perhaps there is some luck in building a team around you with the requisite skills.

"The ecosystem is alive and well where industry, universities, government, professional service firms, support organizations, and others interact beneficially. There has never been a better time... and the help is there, you just have to decide you're going to take it."

Dan Silivestru from an article in Open Source (January 29, 2015) with the heading: "bitHound puts out features, not fires." Silivestru recounts how his foray into IT began when a friend introduced AS/400 systems to him. He recalls "the opportunity and big break" to move in that direction. As someone whose business is about writing code, he had the following advice. "Don't just write code, consider what you are doing as a craft. It is all about product. It takes time, and practice, and it takes time to build something that is resilient and beautiful. Open source is a great way to perfect that craft. One reason we built the dependency tool into our product was to get more people diving into code they can contribute to. Seeing other people's architectures will expose you to better approaches. He also recalled that he had some tremendous mentors along the way."

Chris Reid writes: "Being an entrepreneur is such a beautiful opportunity, and it is very much what you make of it. Sometimes you get knocked out; sometimes you win. You meet and work with those you can attract to your side. You ride market inefficiencies, bubbles and busts. People cheer, people sneer; sometimes you're rewarded." And elsewhere: "A lot of time as a founder, I'm flying around with no idea what I'm doing... the amount of newness in your day is insane. You've got to think fast and wing it. Presumably, you have a great team, you don't scare easily, and you work extraordinarily hard to make it happen... it's almost impossible to know what normal should look like. My prior two tech ventures were not huge successes... but for me, in retrospect, they were critical, incredible and important in many ways." And reflecting back: "It was 2000, and at that time, Waterloo was an ecosystem devoid of mentorship, funding, accelerators or anything useful to start-ups. You could count the number of software start-ups on your hands - it was nothing like it is today. It was lonely, uninteresting, and stressful."

Ted Hastings in Bowen's (2011) book states that raising substantial sums of money provides validation and motivation, forcing a young entrepreneur to move forward at ever-increasing speed. He shares on the following topics: "purpose - you have to care; people - work alongside a team of all-stars, turn to your business partners and request help; the business - everything matters, the big picture and minutiae of the operation."

From Glenn Thorpe's interview questions (WordPress October 7, 2013) Hastings responds: "The ecosystem that exists here has definitely served me well since the day I graduated from WLU to many years later. There've been people that have always been looking out for me and willing to help me out in my career... I've been surround by a core team for about 13 years... I think if you want to have a long and at times successful career you need to maintain your competitiveness to have a chance. You can't teach someone to be competitive. Your reach must exceed your grasp." 
Ali Asaria recalls that when he was getting started with Well.ca the biggest problem was being taken seriously by suppliers and investors. In an interview with Tech Vibes (November 25 (2010) he offers some advice to new entrepreneurs: "Figure out what you really want and keep returning to that. Starting a company takes a lot of work: It can take all your time and it can sap all your self-confidence. Among the biggest challenge is finding the very best people to join the team - people who understand the unique business model but also reflect and enhance the your company's culture."

\section{Conclusions}

Serial entrepreneurs are situated within a community, in this case within the Waterloo Region's entrepreneurial ecosystem. They contribute to and draw from a network of individuals, organizations, and other resources within this setting. Twelve serial entrepreneurs were profiled within one ecosystem in order to provide insight about the development of multiple ventures over time. Although this study did not answer the question on why they were able to establish multiple ventures, there are indications that the ecosystem is a major contributor to their success. The system not only gives them an environment conducive to continued entrepreneurship but provides them with satisfaction and affirmation in what they do.

The serial entrepreneurs in our sample highlight some of the considerations faced in the process of leading their ventures. Our approach does not analyze or provide the specific details in the entrepreneurial process but there are patterns that emerge in the subsequent development of businesses over time. In this study, we have observed that entrepreneurship is a cumulative process. The entrepreneurs continued to found another enterprise even after their first venture. In many instances the new ventures were started even though they had successfully sold off the previous venture. The wealth that had been created did not deter them from starting another venture. In some cases they took some time off to invest or recycle the profit back into the Waterloo ecosystem rather than immediately start another venture.

A review of the serial entrepreneurs in our sample does suggest that the ecosystem itself-the environment in which they work-promotes subsequent rounds of innovation and commercialization. For example, a few started their next venture with a partner from within their ecosystem-primarily because that person already had entrepreneurial experience that would be valuable in the next venture. A few built their ventures with students who already had been a co-op student or had experience within the ecosystem. The social networks for the owner of a business expand with each successive venture, with their work as an advisor or mentor, or with their help as an angel investor.

In the "Serial entrepreneurs: ventures and contributions in the ecosystem" section, we find that many of the serial entrepreneurs in our sample made significant and unique contributions to the ecosystem. These included a commitment to helping other entrepreneurs and organizations as well as a commitment to recycle the wealth created back into the local ecosystem. These contributions were often quite substantial in terms of the benefits they provide entrepreneurs within the Waterloo ecosystem, perhaps just the encouragement or direction they needed to take their business concept forward. 
While we were impressed with the benevolence exhibited by our sample of serial entrepreneurs, we were not surprised. Waterloo's entrepreneurial ecosystem has most of the characteristics or descriptors of a mature ecosystem (see Table 1). These factors promote the growth and development of new ventures. There is no doubt that an environment where innovation and commercialization thrive provides a huge boost to entrepreneurs. Like many others, Randall Howard has asserted that there is something particular about Waterloo. It has developed a unique "sense of place"-one that has been recognized globally.

The final section-Serial entrepreneurs: what they have learned-provides insight into what makes them tick. Their statements give us a clearer picture of how they achieved success. Some of the factors they think are important are: choice of people on the team; strategic focus/plan; getting input/exchanging ideas; enjoying what they do; and having a supportive ecosystem. In essence, we have a 'look back' into how they were able to succeed. Their comments paint a picture of them as optimistic, energetic, and enthusiastic. They seem to love what they do. As one stated, "I wouldn't want to do anything else but be an entrepreneur!"

We readily admit we see much passion in our sample of serial entrepreneurs. The 12 serial entrepreneurs that were reviewed are leaders. The drive runs deep and the success stories about their businesses would have been written even if they were not the specific businesses that we have chronicled. Their footprints are everywhere within the ecosystem. Their many ventures are a good sign that others will take up the challenge and continue in the footprints they leave in the Waterloo ecosystem.

\section{Endnotes}

${ }^{1}$ According to The Record (June 6, 2015) "By a conservative count, at least 25 companies in Waterloo Region can trace their roots to PixStream."

${ }^{2}$ See Carayannis and Stewart (2013) for an exploration of the yin and yang of entrepreneurial behavior.

Authors' contributions

The authors contributed equally to this manuscript. Both authors read and approved the final manuscript.

Competing interests

The authors declare that they have no competing interests.

\section{Author details}

${ }^{1}$ Lazaridis School of Business \& Economics, Wilfrid Laurier University, Waterloo, Ontario, Canada. ${ }^{2}$ Schlegel Centre for Entrepreneurship, Lazaridis School of Business \& Economics, Wilfrid Laurier University, Waterloo, Ontario, Canada.

Received: 5 January 2016 Accepted: 14 May 2016

Published online: 20 May 2016

\section{References}

Acs, Z. J., \& Armington, C. (2004). Employment growth and entrepreneurial activity in cities. Regional Studies, 38(8), $911-927$.

Audretsch, D. B., Keilbach, M. C., \& Lehmann, E. E. (2006). Entrepreneurship and economic growth. Oxford, UK: Oxford University Press.

Baluku, M. M., Kikooma, J. F., \& Kibanja, G. M. (2016). Psychological capital and the startup capital-entrepreneurial success relationship. Journal of Small Business \& Entrepreneurship, 28(1), 27-54.

Baron, R. A. (2015). Social capital. In C. L. Cooper (Ed.), Wiley encyclopedia of management (Vol. 3, pp. 1-3). Hoboken, NJ: Wiley.

Baron, R. A., \& Markman, G. D. (2003). Beyond social capital: the role of entrepreneurs' social competence in their financial success. Journal of Business Venturing, 18(1), 41-60.

Bowen, J. (Ed.). (2011). The entrepreneurial effect: Waterloo. Ottawa, Canada: Invenire Books.

Business Insider (April 19, 2015) "Why this woman turned down a fabulous job at Google."

Business Insider (July 2, 2015) "Why a founder on track to take his company public sold it for \$110 million in cash instead."

Canadian Business (September 25, 2007) "6 questions: one-on-one with Razor Suleman, founder and CEO, I Love Rewards, Inc." http://canadianbusiness.com 
Carayannis, E. G., \& Stewart, M. R. (2013). Obsessed maniacs and clairvoyant oracles: Empirically validated patterns of entrepreneurial behavior. Journal of Innovation and Entrepreneurship., 2(2), 24.

Davidsson, P., \& Honig, B. (2003). The role of social and human capital among nascent entrepreneurs. Journal of Business Venturing, 18(3), 301-331.

Feld, B. (2012). Startup communities: building an entrepreneurial ecosystem in your city. Hoboken, NJ: Wiley.

Fritsch, M. (2008). How does new business formation affect regional development? Small Business Economics, 30(1), 1-14.

Global Start-up Ranking 2012. http://startup-ecosystem.compass.co/ser2012/

Grebel, T. (2007). Entrepreneur- a new perspective. London, UK: Routledge.

Grebel, T., Pyka, A., \& Hanusch, H. (2003). An evolutionary approach to the theory of the entrepreneur. Industry and Innovation, 10(4), 493-514.

Hathaway, I. (2013). Tech starts: high technology business formation and job creation in the United States. Kansas City, KS: Kauffman Foundation.

Isenberg, D. (2011). The entrepreneurship ecosystem as a new paradigm for economic policy: principles for cultivating entrepreneurship. In Babson Entrepreneurship Ecosystem Project. Babson Park, MA: Babson College.

Lengyel, B., Varga, A., Ságvári, B., Jakobi, Á., \& Kertész, J. (2015). Geographies of an online social network. PloS One, 10(9), e0137248.

Mason, C., \& Brown, R. (2014). Entrepreneurial ecosystems and growth oriented entrepreneurship. Paris, France: Final Report to OECD.

Metcalfe, J. S. (2004). The entrepreneur and the style of modern economics. Journal of Evolutionary Economics, 14(2), 157-175.

Morris, M. H., Kuratko, D. F., Schindehutte, M., \& Spivack, A. J. (2012). Framing the entrepreneurial experience. Entrepreneurship: Theory and Practice, 36(1), 11-40.

Napier, G. and Hansen, C. (2011) Ecosystems for young scalable firms. FORA Group.

Open Source (29 January 2015) "bitHound puts out features, not fires." http://opensource.com

Rey-Martí, A., Porcar, A. T., \& Mas-Tur, A. (2015). Linking female entrepreneurs' motivation to business survival. Journal of Business Research, 68(4), 810-814.

Schumpeter, J. A. (1934). The theory of economic development. Cambridge, MA: Harvard University Press.

Spivack, A. J., McKelvie, A., \& Haynie, J. M. (2014). Habitual entrepreneurs: possible cases of entrepreneurship addiction? Journal of Business Venturing, 29(5), 651-667.

Tech Talk (2012) http://www.youtube.com/watch?v=UcyJaFkhAbw

Tech Vibes (November 25, 2010) "How Ali Asaria built Well.ca into Canada's largest online health and beauty store." http://techvibes.com

The Record (December 10, 2011) "Passion for business takes entrepreneur from software to cars to music." http:// therecord.com/waterlooregion/

The Record (June 6, 2015) "Roots and branches: short-lived PixStream seeded host of tech startups in Waterloo Region." http://therecord.com/waterlooregion/

Ucbasaran, D., Westhead, P., \& Wright, M. (2001). The focus of entrepreneurial research: contextual and process issues. Entrepreneurship: Theory and Practice, 25(4), 57-80.

Ucbasaran, D., Westhead, P., and Wright, M. (2008) Habitual entrepreneurs. In M. Casson, B. Yeung, and A. Basu (eds.) The Oxford handbook of entrepreneurship. Oxford University Press on Demand. Accessed 27-03-2016.

Unger, J. M., Rauch, A., Frese, M., \& Rosenbusch, N. (2011). Human capital and entrepreneurial success: a meta-analytical review. Journal of Business Venturing, 26(3), 341-358.

Westhead, P., \& Wright, M. (1998). Novice, portfolio, and serial founders: are they different? Journal of Business Venturing 13(3), 173-204.

Westlund, H., \& Bolton, R. (2003). Local social capital and entrepreneurship. Small Business Economics, 21(2), 77-113.

Witt, U. (1998). Imagination and leadership - the neglected dimension of an evolutionary theory of the firm. Journal of Economic Behavior and Organization, 35(2), 161-177.

WordPress (October 7, 2013) "Q\&A with KW's most successful young professionals: Ted Hastings, CEO of Rebellion Media." http://glenndouglasthorpe.wordpress.com

York, J. G., O'Neil, I., \& Sarasvathy, S. (2015). Selective incentives, entrepreneurship, and identity: toward a behavioral theory of collective action. Paper presented at Academy of Management Annual Meeting. Canada: Vancouver.

\section{Submit your manuscript to a SpringerOpen ${ }^{\circ}$ journal and benefit from:}

- Convenient online submission

- Rigorous peer review

- Immediate publication on acceptance

- Open access: articles freely available online

- High visibility within the field

Retaining the copyright to your article

Submit your next manuscript at $\boldsymbol{\wedge}$ springeropen.com 